\title{
Investigating Success Factors on Employee Performance of Accommodation and Food Service Industry in Penang, Malaysia
}

\author{
Sim Joe Fen ${ }^{l}$, Muhammad Shahar ${ }^{l}$, Mohd Rosli $^{l}$ and Dayang Hasliza ${ }^{l}$ \\ ${ }^{1}$ Faculty of Applied and Human Sciences, Universiti Malaysia Perlis, Kangar, Perlis
}

\begin{abstract}
The accommodation and food service market in Malaysia is very active. However, inconsistent with the rapid development of the accommodation and food service industry, accommodation and food service industry generally face problems such as shortage and loss of talent, poor service quality and competition in industry. The purpose of this paper was to investigate the successful factors that affected the employee performance of accommodation and food service industry in Penang, Malaysia. The factors that examine in this paper were training, working environment, reward and leadership. Data was gathered from the employee from accommodation and food service industry in Penang, Malaysia. The research was a quantitative research method. The researcher used a sample size determination table and used cluster sampling technique to select samples to make the samples more representative. The questionnaire was consisted of two section. The five-Likert scale was used to collect the primary data and 201 responses were properly filled and returned. SPSS was used to analyze the data collected through the questionnaire. The frequency, reliability and descriptive were calculated and explained. The results showed that there was a positive correlation between all independent variables and dependent variable. It was found that the effect of the independent variables on dependent variable was $52.9 \%$, while the remaining 47.1 were affected by factors that were not covered by this study. In this study, it also found that training and working environment have a significantly impact on employee performance, however, reward and leadership have no significant impact on employee performance. Based on the findings, the research results were discussed and recommendations are provided for managers and future research.
\end{abstract}

Key words: Employee performance, Training, Working environment, Reward, Leadership

\section{INTRODUCTION}

Performance generally includes two aspects: on the one hand, it refers to work results, such as the effectiveness of the work and the benefits generated by the work; on the other hand, it refers to the key behaviors, skills, abilities and qualities that affect the results of the work. In the theory and practice of management, the basic meaning of performance is performance and effect, which can be defined as the performance and results obtained by individuals, teams or organizations engaged in an activity. In 1970s, the endeavors of profession arranging and advancement were mostly devoted on youthful representatives those exhibit to have a high potential. It has been proposed for the associations to make arrangement for future and give preparing and improvement to their new workers for the highpositioning situations in future [1].
In an unpredictable business environment and fierce business competition, companies are required to meet certain standards by improving performance to meet such high requirements. Otherwise, many problems will arise, including the risk of closing the business. This performance is related to the company or individual level, which considers human resources to be the most decisive factor in achieving organizational goals. In fact, without the support of qualified human resources that directly disrupt the continuity of business operations, large resources such as infrastructure or physical facilities become meaningless. Within the framework of the professionals, good employee performance mirrors the ability to contribute through their works leading to the behavioral achievement that is in accordance with the goals of the company [2]. At the same time, the degree of business success depends on the performance of human resources management. 
In short, performance is the comprehensive performance of employees in an enterprise. It involves employees' working attitude, ability and performance, as well as their development prospects and the need for future training. Performance management is a set of systematic management activities established between organizations and individuals. It is mainly used to evaluate employees' work ability and performance and the degree to which their results are achieved. It is hoped that by providing employees with appropriate growth and development training, they will achieve their goals possibility and effectiveness of the overall organization.

The growth of interest in employees' performance is not the latest topics that are being discussed in these years. Many studies have been done in western and others Asian Country. Malaysia's accommodation and food service industry are becoming more and more developed. However, it is not compatible with the rapid development of the accommodation and food service industry. Malaysia accommodation and food service industry generally face the problems such as talent shortage and loss, poor service quality, and fierce competition in the industry. Among them, talent shortage and loss are the most serious. If an accommodation and food service industry want to become bigger and stronger, it must be invincible in the fiercely competitive accommodation and food service market, it must have all kinds of talents, otherwise the industry will not get the long-term development. Therefore, in the era of talent competition, employees, especially excellent employees are the most valuable wealth of the accommodation and food service industry. The loss of excellent employees has a huge negative impact on accommodation and food service industry.

In order to better operate human capital and get rid of the dilemma of excessive talents and employee shortage, the Malaysia accommodation and food service industry urgently needs to consider ways to improve the employee performance. This study draws on relevant professional theories such as human resource management and the actual situation of the Malaysia accommodation and food service industry, and plan to outline effective factors to improve employee performance of accommodation and food service industry in Penang, Malaysia.

Training is a systematic process aimed at enhancing employees' skills, knowledge, and abilities, which is necessary for effective job execution. Overall, training will affect the organization's competitiveness, income and performance. Unfortunately, most governments, private organizations, and international organizations are unaware of the importance of training for improving employee productivity, and when the economy slows or profits decline, many organizations first seek to cut training budgets. This will result in a higher rate of job loss, and then increase the cost of hiring new employees, thereby reducing the profitability of the organization. Past research has proven that there is a positive link between training and employee performance, because training has a positive impact on employee performance by enhancing employee capabilities and behavior, thereby bringing benefits to employees and the company. Companies that value shareholder and customer satisfaction recognize the importance of investment training and therefore recognize the value of employee development [3]. The previous studies did not focus on the accommodation and food service. Hence, this study focused on impact of training on employee performance in accommodation and food service industry.

Most organizations do not care about the working environment, good office design and employee motivation. People who work in these organizations are not satisfied with their work and are not willing to work in a better way. Therefore, it is difficult for them to achieve the best performance. Therefore, due to the unfavorable working environment, uncomfortable office design and lack of motivation, the performance of employees declines. It is by and large accepted that the workplace has a positive or negative effect on employee performance. The working environment significantly influences how much representatives take part in work and are focused on organization. Evacuated employees produce average outcomes; highly dedicated employees produce remarkable outcomes. Therefore, it is important to consider the effect of the working environment in the organization on the employee performance. The previous studies have focused on the physical environment of working environment. Hence, this study examines the working environment in employee relations.

It was proved that the performance reward system has two advantages in practice [4]. Attract highquality employees, and secondly encourage employees to make more efforts in their work. Is there evidence that these plans are capable of supplementing the quality of service based on employees' work output? How do they make positive contributions to job performance and reward? The previous studies have focused on both financial reward and non-financial reward on the employee performance. Hence, this study examines the financial reward on employee performance.

Employee performance includes performing defined responsibilities, completing tasks on time, employee capabilities, and work efficiency and efficiency. Various organizations need strong 
leadership to stimulate employee performance. Some organizations face problems such as poor innovation, low productivity, and failure to achieve performance goals. The reason for this problem is that due to the lack of strategic intervention for specific leadership styles in specific situations, this is expected to be the current problem. This issue continues to affect employee performance. This is why survey research can inspire the best way to lead employee performance. It is believed that effective organization stems from propellers or business leaders. The idea of effective leadership is also adopted in the technical field. Employees also believe that not only leaders but effective leaders are needed. Therefore, they need an effective leader who can lead people in the direction of change and performance improvement. The previous studies have focused on the types of leadership style will influence employee performance. Hence, this study examines the combination of all types of leadership style on employee performance.

Among the previous studies, there were contextual gaps between their research and this research. The reasons to do this research was because there was lack of previous research in the accommodation and food service industry but in the other sectors such as manufacturing industry, bank industry and others. Other than that, the previous researches were done in other country but not in Malaysia. This research was targeting the employee performance in the accommodation and food service industry in Penang, Malaysia. The results of this study provide a basis for managers to understand the relationship between these elements, which are the key to improving performance results. There was lack of research combine all the training, working environment, reward and leadership as the success factors on employee performance. This research was investigating all the training, working environment, reward and leadership as the success factors on employee performance.

This research can help the university to know their student behaviour hence it can help the association using a right technique to influent their student to purchase ecological product as a support to reduce the environment issues such as global warming.

\section{LITERATURE REVIEW \\ Employee Performance Theory}

\section{Herzberg Theory}

Two Factor Theory also known as MotivatorHygiene Theory. It was proposed by Fedrick Herzberg, a behavioral scientist in the United State. The factors that bring positive attitudes, satisfaction and reward are called "reward factors". These are the factors that can meet the needs of personal self- actualization, including achievement, appreciation, challenging work, increased job responsibility, and growth and development opportunities. If these factors are in place, they can generate greater incentives for people. In this sense, Herzberg believes that traditional incentive assumptions, such as salary incentives, improved interpersonal relationships, and providing good working conditions, will not produce greater incentives; they can eliminate dissatisfaction and prevent problems, But even if these traditional "motivating factors" reach the optimal level, they will not produce positive incentives. Only "motivating factors" can make people have better work performance.

In Herzberg's hypothesis, cleanliness factors don't motivate employees and are related with momentary impacts. Sparks, then again, for the most part have long haul impacts. Helpers center around inborn factors, for example, expanded self-rule, accomplishment, rewards, expanded employment responsibility, and professional success [5]. Herzberg's theory had a relationship with remuneration on employee will influenced on employee performance.

\section{Employee Performance}

The term "performance" is derived from management, and different scholars have interpreted it differently. [6][7] "Performance is a set of behaviors related to a certain work and organizational goal in an organization."

Performance is the result of work, and the results of these efforts are most closely related to the organization's strategic goals, customer satisfaction, and investment [8]. Literally, performance consists of achievements and effects of the company after investing in certain factors in order to achieve its goals. According to the activity participants, performance can be divided into individual performance and organizational performance. In the case of companies, individual performance is expressed in the organization as the quantity, quality, cost, and other tasks of the job. The realization of organizational performance is based on individual performance. The realization of individual performance does not guarantee the effectiveness of organizational performance. The enterprise only assigns the performance of the organization to the work of each employee, and each employee can complete the tasks required by the organization to achieve organizational performance. Therefore, improving employee performance is a prerequisite for improving organizational performance.

Researchers and scholars have their own opinions. Therefore, it is very difficult to give a clear definition of performance. According to the 
Webster's dictionary, performance refer to completion execution behavior, accomplishing a certain task or achieving a certain goal, usually with functional or effective energy. In fact, performance includes both work outcomes and work behavior.

\section{Training}

Implementation of job training intended to obtain employment who have the knowledge, skills, ability and a good attitude to fill positions available jobs with high labor productivity, which can produce good work [9]. Training is any attempt to improve performance on a task that is responsibility. Ideally, training should be designed to achieve the objectives of the organization, which at the same time also realize the objectives of the individual workers.

After a performance management cycle, the results of the performance appraisal were determined, the performance of the employees was analyzed based on the results, and the part of the appraisers that affected the performance level was trained. The human resources department designs an overall training and development plan based on the areas that need to be improved in the current performance of employees, and helps supervisors and employees implement training and development together.

\section{Working Environment}

The physical types of working environment were space, physical design, clamor, devices, materials and co-worker's relationship; the nature of those angles has a significant and positive effect on the nature of the work [10]. The working environment was where employee complete exercises, which can have positive and negative consequences for employees' outcomes. An ideal working environment goodly affect the continuity of employment, while an unfavorable working environment will have an adverse effect on the continuity of employment.

Work environment is stated as the physical environment where it affects the employee performance, security and quality [11]. The work environment provides safety and enables employees to work optimally, and it can affect their emotions. If an employee likes his working environment, he will like his time in the workplace to do such activities, he will effectively and most effectively utilize his working time, and his work implementation will be high. In addition to the physical condition in which employees work, the working environment also includes working connections among colleagues and the relationships between subordinates and their superiors.
The environment was a major idea for employee performance. It includes things that the human body can contact and see. It tends to be an equipment situation such as office and lighting conditions, or it very well may be a working atmosphere. Environment factors influence employee performance by improving individual efforts and awareness of responsibility. Here, we partition environmental factors into four angles: equipment working environment, enterprise management mechanism, corporate culture and reference group. Employee performance is influenced by the workplace, for example, the organization's arrangements, fulfillment with the manager or colleagues, just as material factors, for example, lighting, clamor, security, accommodation and solace.

\section{Reward}

Reward is a wide develop that has been said to speak to whatever an employee may esteem that a business is willing to offer in return for his or her contributions [12]. The absence of rewards will make an unsavory situation, therefore decreasing employees' work endeavors and may make them with draw from their occupations. Therefore, rewards are progressively significant. The primary objectives of rewards were to attract and hold employees, to motivate employees to accomplish high levels of performance, and to elicit and reinforce desired behavior of the employees. Organizations regularly utilize monetary rewards to prevent employee disappointment and to motivate employees despite the fact that it may not be the best helper as long as possible [13].

Rewards have two broad types; extrinsic and intrinsic rewards are also called financial and nonfinancial rewards. Extrinsic rewards related to financial rewards or cash related like formal recognition, fringe benefits, incentive type payments, pay, promotion and intrinsic relates to non-financial or non-cash rewards like achievement, accomplishment feelings, recognition, job satisfaction and growth [14].

\section{Leadership}

Leadership is a significant part of making and improving leadership success in an organization. "Leadership style is a set of accepted rules utilized when somebody attempts to impact the conduct of others or subordinates [15]." Leadership style is a set of leaders used to impact subordinates. In order to accomplish the qualities of organizational objectives, it can also be said that leadership style is a leader's liked and frequently received conduct and technique model [16]. 
Leadership style is a route utilized by the leader impact, direct, energize and control others in accomplishing objectives [17]. Leadership is the ability to impact others to help the applicable accomplishment of the organization [18]. The pattern of all leader actions as perceived or referred by the subordinates is known as leadership style [19].

An effective leader are leaders who can change their behavior based on the characteristics of the follower and the circumstances in which the leadership occurs. In other words, leadership depends or contingent on the followers it leads and the environmental situation in which leadership take place [20].

\section{Hypothesis Development}

\section{Training and Employee Performance}

The study of past researcher proved that partially significant effect of training on employee performance [21]. Employees with good performance can be described as having ample opportunity to participate in various training appropriate to desired competencies. Implementation of training intended to obtain employment ho have the knowledge, skills, ability, and a good attitude to fill positions available jobs with a high labor productivity, which can produce good performance [9]. Training effects on behavior of employees and their working skills which resulted in enhanced employee performance and further constructive changes [22] that serves as increase employee performance [23].

Training has a positive impact on employee performance. In a qualitative study of Indian mechanics, [24] believes that the direction of hands of training is curiosity and innate aptitudes. Technology and expertise are important for employees to do their jobs effectively. Providing employees with training opportunities can improve employee performance.

H1: Training significantly influence the employee performance.

\section{Working Environment and Employee Performance}

The working environment is defined the environment where the employees perform tasks and work every day [25]. And also, everything that exists around the employee and may affect the employees in performing his or her duties" [26]. However, in other study that investigates the impact of workplace environment and infrastructure on employee's performance [27]. Analysis and interpretation of the data have empirically demonstrated that infrastructure at workplace had no significant impact on employee performance. In another study shows that job performance is very much influenced by work environment and reward of workers [28]. The study also confirms that the hotel industry needs to consider improving its environmental factors to boost employee performance.

H2: Working Environment significantly influence the employee performance.

\section{Reward and Employee Performance}

There are different intends to reward employees that do not simply concentrate on financial compensation [29]. A portion of these incorporate the lauded that can procure from their supervisors, the chance to take on significant activities or assignments, and even authority consideration. Much research on leader power had discovered that director reward force would be decidedly connected with employee task performance, efficiency, fulfilment, turnover, and organizational citizenship behaviors. When employees feel or believe their efforts will be rewarded by management, they will make the most of it. Many researchers have found that employees' job satisfaction is affected by both financial and nonfinancial rewards. An ineffective reward management will affect employees' satisfaction and de-motivate them, hence affecting their performance outcome. The study of past researcher also shows that the compensation and reward are both influence on the employee performance [30].

\section{H3: Reward significantly influence the employee performance.}

\section{Leadership and Employee Performance}

The outcome in the study of [31] showed that leadership style conveyed a critical and beneficial outcome toward employee performance, which implied that leadership style was one of the significant factors that can improve employee performance. This is in line with the study of previous researches [17]; [28]; [31] and [33]. Unlike the four studies, [34] noted that leadership style did not have a significant and positive impact toward employee performance.

Leader behavior is one of the important factors that can affect employee job performance [20]. A close relationship and mutual help with co-workers and leader were very important and has a strong relationship with job satisfaction [35]; [36], the better the leader in supervising employees more comfortable and satisfied also the employees in doing their work, and vice versa. 
H4: Leadership style significantly influence the employee performance.

\section{Summary}

In conclusion, chapter 2 explained the literature review of this research. The independent variables and dependent variable of the research were discussed in this chapter. Besides that, the hypotheses were also stated in this chapter. Chapter 3 will explain about the research methodology of this research.

\section{METHODOLOGY}

The theoretical framework is the structure that can hold or support a theory of a research study. The theoretical framework introduced and described the theory that explain why the research problem under study exists. Other than theorical framework, this chapter also consisted research methodology, target population, sampling method, sampling location, sampling frame, questionnaire design, list of measurements, unit of analysis and statistical analysis.

Theoretical Framework

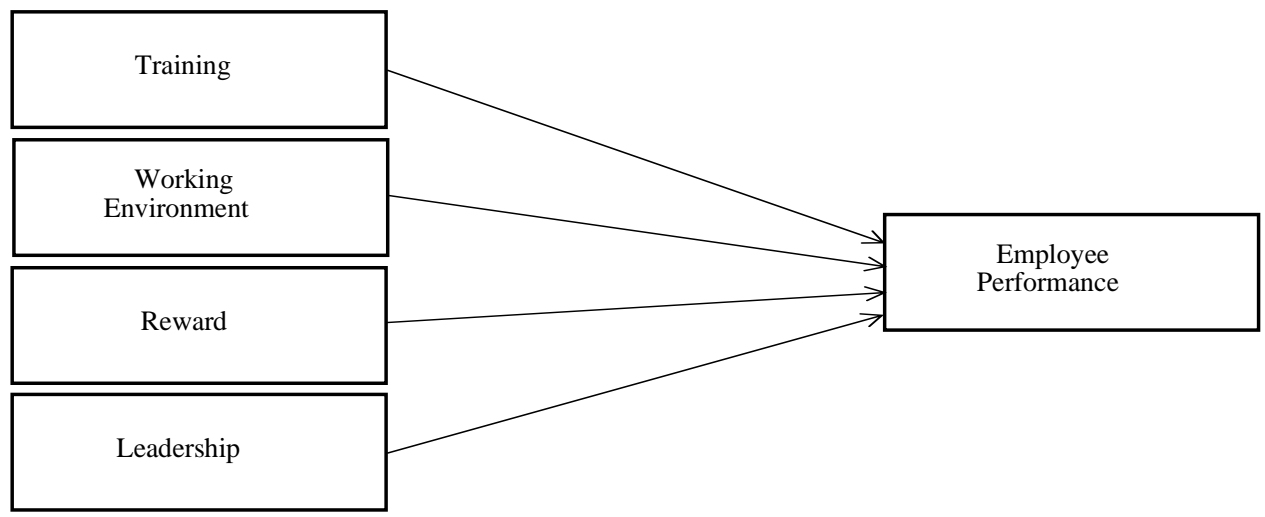

\section{Independent Variables Dependent Variables}

Figure 3.1 Theoretical Framework for the influence of training, working environment, reward and leadership towards employee performance

\section{H1: Training significantly influence the employee performance.}

H2: Working Environment significantly influence the employee performance.

H3: Reward significantly influence the employee performance.

H4: Leadership style significantly influence the employee performance.

Figure 3.1 showed that the theoretical framework developed for this research. This theoretical framework consisted of four independent variables which are training, working environment, reward and leadership style whereas the dependent variable for this research was employee performance. This research was studied to determine the relationships between training, working environment, reward, leadership style and employee performance in details. It also indicated the influence of training, working environment, reward and leadership style towards employee performance.

\section{Research Design}

Research design helps researchers obtain relevant data to achieve research goals [37]. As indicated by [38], the research design is a conceptual structure in which research is carried out; it establishes a blueprint for data collection, measurement and analysis. It guarantees that examination is pertinent to the issue and uses economic procedures. This research is a quantitative study because researchers want to identify the factors that influence employee performance. A quantitative research design was set up to collect data. Quantitative methods help researchers test the relationship between variables [39]. Researchers believe that this research method provides relevant data on research topics and supports meeting research objectives because it can involve collecting and analyzing numerical data and applying statistical tests. In this study, a quantitative method was implemented as recommended by [39]. This research was going to study about the factors of training, working environment, reward and leadership that can affect the employee performance in accommodation and food service industry in 
Penang. The survey technique used was quantitative research method which collecting the data by using questionnaire. Quantitative research method was used in this study because this study used formal questions and predetermined response selection in

Data collection that used in this study was primary data. Primary data is the data that collected in questionnaire. The questionnaire completed by the respondents and their participation were purely voluntary. The respondent will be the employees works in accommodation and food service industry Penang, Malaysia. By using the questionnaire, it allows the researcher to get the data from respondents more quickly.

\section{Sampling Design}

The target population was the total number of individuals from which the sample might be drawn. The target population was also called as target audience which is a particular group of people. The target population in this study was the employees works in the accommodation and food service industry, Penang. There are consisted 79,300 employees according to Labour Force Survey, Department of Statistics, Malaysia.

Table 3.1: Number of employed persons in Penang, Malaysia

\begin{tabular}{lc}
\hline & $\begin{array}{c}\text { Total } \\
\text { employee } \\
\text { ('000) }\end{array}$ \\
\hline Employed Persons & 830.8 \\
$\begin{array}{l}\text { Employed Persons in sector } \\
\text { Accommodation and food service }\end{array}$ & 79.3 \\
\hline $\begin{array}{l}\text { Source: Labour Force Survey, Department of Statistics, } \\
\text { Malaysia 2018 }\end{array}$
\end{tabular}

The target population in this study was employed person by accommodation and food service industry which consisted of male and female employees. The total population of Accommodation and Food Service employees in Penang, Malaysia was 79,300. According to the table of determining sample size, the sample size for the population of 79,300 was 382 [41]. Therefore, the total sample size in this survey yielded 382 respondents that targeted the employees in Accommodation and Food Service, Penang who completed responses were used in the analysis. Their participations were purely voluntary.

\section{ANALYSIS}

\section{Reliability and validity}

Reliability analysis was measured via Cronbach's coefficient alpha to check for internal consistency of the constructs. All constructs have no problems in reliabilities if the Cronbach's Alpha value exceeded survey questionnaires and it was given to a large number of respondents [40]. The questionnaire was distributed to the employee that work in the accommodation and food service industry in Penang, Malaysia to get the data information.

the criteria of 0.700 [37]. Table below illustrated that all of the variables was exceeded the criteria of 0.700 Cronbach's Alpha which all were considered as acceptable reliability. The table also showed the highest value of Cronbach' Alpha was 0.873 for the leadership style which was one of the independent variables. However, the lowest value of Cronbach's Alpha was 0.712 for the dependent variable, employee performance. Thus, the survey instrument was reliable to measure all the constructs consistently and free from random error.

Table 3.11: Reliability Analysis of Pilot Test

\begin{tabular}{|l|c|c|l|}
\hline Variables & $\begin{array}{c}\text { No. of } \\
\text { Items }\end{array}$ & $\begin{array}{c}\text { Cronbach's } \\
\text { Alpha }\end{array}$ & Remarks \\
\hline $\begin{array}{l}\text { Employee } \\
\text { Performance }\end{array}$ & 3 & 0.712 & Acceptable \\
\hline Training & 5 & 0.800 & Acceptable \\
\hline $\begin{array}{l}\text { Working } \\
\text { Environment }\end{array}$ & 5 & 0.778 & Acceptable \\
\hline Reward & 4 & 0.818 & Acceptable \\
\hline $\begin{array}{l}\text { Leadership } \\
\text { Style }\end{array}$ & 5 & 0.873 & Acceptable \\
\hline
\end{tabular}

\section{CONCLUSION}

This research studied the success factors toward the employee performance of accommodation and food service industry in Penang, Malaysia. The research explained about the relationship between independent variables that were training, working environment, reward and leadership that influence the dependent variables of the employee performance of accommodation and food service industry in Penang. The result of the research explained in this part.

The first objective of this research was to test is training significantly influence the employee performance of accommodation and food service industry in Penang. Based on the result of SPSS statistics after analyze the data collected form the respondents, it showed that the $\mathrm{p}$-value was 0.000 which was less than 0.05 , means that the training was significantly influence the employee performance of accommodation and food service industry in Penang. Therefore, H0 has been rejected and $\mathrm{H} 1$ accepted. This result supported by [21] that results of the regression analysis prove that training has a significant impact on employee performance. Employees with good performance can be said to 
have enough opportunities to participate in various trainings that are suitable for the required abilities.

The second objective of this research was to test is working environment significantly influence the employee performance of accommodation and food service industry in Penang. Based on the result of SPSS statistics after analyze the data collected form the respondents, it showed that the $\mathrm{p}$-value $=0.002$ which is less than 0.05 . This result showed that the working environment was significantly influence the employee performance of accommodation and food service industry in Penang. Therefore, HO has been rejected and $\mathrm{H} 2$ is accepted due to the result. This result was consistent with a previous study done before which shown that the working environment significantly influence the employee performance with $\mathrm{p}=0.059$ of low level of contribution [43]. This results also supported by the previous study form [44]. The results are consistent with previous studies conducted by [45], [46] and [47].

The third objective in this research was to test is reward significantly influence the employee performance of accommodation and food service industry in Penang, Malaysia. Based on the result of SPSS statistics after analyze the data collected form the respondents, it showed that the p-value was 0.159 which was exceed 0.05 and the unstandardized coefficients $t$-value $=1.413$ less than 1.649. This result means that the reward was not significantly influence the employee performance of accommodation and food service industry in Penang. Therefore, Ho was accepted while H3 has been rejected. The cash bonuses did not seem to have much impact on employee performance they were only more satisfied than those without rewards. This results also can be supported by a previous study done before which found that cash bonuses had no significant impact on employee performance. Those who accepted and did not accept it thought it also affected their performance; therefore, it had no significant effect on performance [48].

Last but not least, the fourth objective in this research was to test is leadership significantly influence the employee performance of accommodation and food service industry in Penang, Malaysia. Based on the result of SPSS statistics after analyze the data collected form the respondents, it showed that the p-value was 0.901 which was exceed 0.05 and the unstandardized coefficients $\mathrm{t}$-value $=-0.125$ less than 1.649. This result means that the leadership was not significantly influence the employee performance of accommodation and food service industry in Penang. Therefore, Ho was accepted while H4 has been rejected. There were many researches that showed that the employee performance was significantly influenced by the leadership. This result had been supported by the previous research [49] with some leadership styles do not affect employee performance. Most people agree to adopt a transformative leadership style, but leaders need to improve, especially in terms of the ability of leaders to create a beneficial work atmosphere and leaders 'policies to reward employees who perform well. The results of this study are inconsistent with the results of previous studies [50]; [51]; [52]; [53]; [54]. They found that leadership had a positive and significant effect on employee performance.

Using the SPSS system, the researchers were able to explain the factors that influence employee performance of accommodation and food service industry in Penang and came to the results. Form the results, it is obvious that independent variables including training, working environment, reward and leadership are closely related to employee performance of accommodation and food service industry in Penang.

The results prove that the training had the greatest influence on the employee performance of accommodation and food industry in Penang among the four independents variables. This means that company should make improvement on their training program to maintain or improve their employee performance. Employee training is the driving force and energy for continuous growth of employees. In the era of knowledge economy, such training was also important condition for company to attract talent and retain talents. Therefore, company should carry out and training throughout the entire career of employees, so that employees can continuously update their knowledge and technology in a timely manner. The training should be based on the personal qualities, potentials and ambitious plans of the employees of the company. Training according to aptitude and different from person to person was the rule of training, and it was also the rule that companies must follow to carry out the training.

The results from SPSS statistics also showed that the working environment was another important consideration for company on employee performance. The working environment includes office environment, corporate culture and employee relations. The requirements of employees on the external environment are not the conditions for employees to be satisfied with the company, but it was the factors that make employees unsatisfied with their work. A good office environment allows employees to have no dissatisfaction with his work, and does affect employee performance. Other than that, if the coordination between departments or employees was not smooth, it will seriously affect the overall efficiency of the company. The 
relationship between employees will often have a greater impact on the link where the collaboration really landed, but it is easy to be ignored or observed. Good employee relations can naturally encourage collaboration among employees. If the relationship between employees is complex in a company, it will become a natural barrier for employee collaboration, which will affect employee performance. Company can try to have some event or party that can help in increase the relationship between employees.

In this research, it showed that the reward was not significantly influenced the employee performance. However, it showed significant influenced employee performance in another research. In research of [30], the results showed that compensation and reward have a significant impact on employee performance. It is known that reward have a positive effect on employee performance. However, there were no perfect reward system, because reward is personal, and the motivation to motivate one employee may be different from the motivation to motivate another employee. Therefore, organizations should fully understand their employees so that they can adopt the correct reward system. Cash bonuses have little effect on company performance. Cash bonuses only seem to please employees and prevent them from being dissatisfied, but it does not seem to have an impact on employee performance.

The results from SPSS statistics also showed that the leadership did not significantly influenced the employee performance. Different situations require different leadership styles. When it takes little time to reach an agreement and needs to work quickly, and the designated authorized institution has more experience or expertise than other departments in the team, an authoritarian leadership style may be the most effective, but it must be highly the enthusiasm and unity of the team with the same level of professional knowledge, more participatory and democratic style may be more effective. This style should be the one that best meets the goals of the team, while balancing the interests of its followers and team members led by effective leaders. When the correct and appropriate leadership style is used, the leadership style may have a significant impact on employee performance.

There were several limitations faced by the researcher when conduct this research of success factors toward employee performance of accommodation and food service industry in Penang Malaysia. Firstly, the researcher feels difficult to reach the number of the respondent need for the research. This also because of the Movement Control Order (MCO) caused the researcher had a limitation when collecting the data. There were only 201 respondents that had been collected by researcher, it was 181 respondents less than the sample size. The number of respondents was based on the number of population and the sample size [55].

In term of time and effort to reach the number of respondents is huge, this caused many of potential respondents unwilling and rejected to spend their time to answer the questionnaire. Besides that, some respondents might not be honest and sincere in answering the questionnaire. For example, some respondents may not fully pay attention to answering each question in the questionnaire, but only answer the question without read the question carefully and simply gave the answer. Therefore, this limits the researcher in understanding deeper about the real intention of success factors towards the employee performance.

Next, this study examined only four independent variables, namely training, working environment, reward and leadership. Apart from these four independent variables, there were no other factors had been studied in this research. However, there are many other factors that might influence the employee performance, such as ability, competence and awareness. Therefore, this leads to the lack of representativeness of the study, and insufficient to understand and describe the factors that affect employee performance.

The researcher recommended the future research should find more ways to distribute questionnaires. This was because effectively distributing the questionnaire will speed up the researcher process and allowed more time to analyze the collected data. For example, the questionnaire can be sent to the related industry and ask the administrator for help, let the employees to answer for the questionnaire. This may speed up the researcher's data collection. Besides that, this study focused only on the employee performance of accommodation and food industry in Penang. The researcher suggested the future research could be conducted in different fields and different population and regions such as survey in Selangor, Perlis or Perak in order to obtain more accurate results to measure the success factors on employee performance. The people in other states or fields might also concerns different factors and different opinion on the employee performance.

Lastly, this research only examined four independent variables which were training, working environment, reward and leadership that affecting the dependent variable which was the employee performance. However, there might be other variables that could affecting the employee performance. The researcher recommended the future researcher could try to look for more success factors that could make the better employee 
performance in accommodation and food service industry or in other fields other states.

\section{REFERENCES}

[1] Moses, B. (1999). Career planning mirrors social change. The Globe and Mail [OnLine]. Retrieved January, 18, 2001.

[2] Muda, I., Rafiki, A., \& Harahap, M. R. (2014). Factors influencing employees' performance: a study on the Islamic Banks in Indonesia. International journal of business and social science, 5(2).

[3] Evans, J. R., \& Lindsay, W. M. (2002). The management and control of quality (Vol. 5, pp. 115-128). Cincinnati, OH: South-western.

[4] Waswa, F., \& Katana, G. (2008). Academic staff perspectives on operating beyond industrial actions for sustainable quality assurance in public universities in Kenya. International Journal of Environment, Workplace and Employment, 4(1), 45-58.

[5] Herzberg, F., Mausner, B. and Snyderman, B.B. (1959) The Motivation to Work. John Wiley \& Sons, New York.

[6] Campbell, J. P., McCloy, R. A., Oppler, S. H., \& Sager, C. E. (1993). A theory of performance. Personnel selection in organizations, 3570, 3570.

[7] Murphy, K. R. (1989). Is the relationship between cognitive ability and job performance stable over time?. Human performance, 2(3), 183-200. N. (2011). Research methods: The basics. London: Routledge.

[8] Bernardin, H. J., Kane, J. S., Ross, S., Spina, J. D., \& Johnson, D. L. (1995). Performance appraisal design, development, and implementation. Handbook of human resource management, 462, 493.

[9] Hasibuan, H. A., Purba, R. B., \& Siahaan, A. P. U. (2016). Productivity Assessment (Performance, Motivation, and Job Training) using Profile Matching. SSRG Int. J. Econ. And Management Stud, 3(6).

[10] Tyssen, R. (2005). The relative importance of individual and organizational factors for the prevention of job stress during internship: a nationwide and prospective study. Journal Medical Teacher. Vol. 27, 2005 - Issue 8

[11] Heizer, Jay \& Render, Barry (2001). Operation Management. Prentice Hall

[12] Chiang, F. F., \& Birtch, T. A. (2008). Achieving task and extra-task-related behaviors: A case of gender and position differences in the perceived role of rewards in the hotel industry. International Journal of Hospitality Management, 27(4), 491503.

[13] Mossbarger, M., \& Eddington, J. (2003). Methods for motivating employees. Weber State University.

[14] Mottaz, C. J. (1985). The relative importance of intrinsic and extrinsic rewards as determinants of work satisfaction. The Sociological Quarterly, 26(3), 365-385.

[15] Geier, M. T. (2016). Leadership in extreme contexts: Transformational leadership, performance beyond expectations?. Journal of Leadership \& Organizational Studies, 23(3), 234247.

[16] Gençer, M. S., \& Samur, Y. (2016). Leadership styles and technology: Leadership competency level of educational leaders. Procedia-Social and Behavioral Sciences, 229, 226-233.

[17] Kristanti and Harahap, P. (2012), Pengaruh gaya kepemimpinan, komunikasi dan motivasi kerja terhadap kinerja karyawan (studi pada PT. Bank tabungan pensiunan nasional cabang semarang), Dinamika Manajemen USM, Vol. 1 No. 1, pp. 1628.

[18] Ivancevich, J.M., Konopaske and R., Matteson, M.T. (2008), Organizational Behavior and Management, 8th edn, McGraw-Hill, NY.

[19] Newstrom, J. and Davis, K. (2007). Organizational Behavior: Human Behavior at Work, McGraw-Hill, New Delhi.

[20] Sylvester, K., 2016. Chapter 2 - Attributes of Effective Leader-Negotiators, in: Sylvester, K. (Ed.), Negotiating in the Leadership Zone. Academic Press, San Diego, pp. 11-22. https://doi.org/10.1016/B978-0-12-8003404.00002-3

[21] Thaief, I., \& Baharuddin, A. (2015). Effect of training, compensation and work discipline against employee job performance. Rev. Eur. Stud., 7, 23.

[22] Satterfield, J. M., \& Hughes, E. (2007). Emotion skills training for medical students: a systematic review. Medical education, 41(10), 935-941.

[23] Kraiger, K. (2002). Creating, implementing, and managing effective training and development: State-of-the-art lessons for practice. Jossey-Bass.

[24] Barber, J. (2004). Skill upgrading within informal training: lessons from the Indian auto mechanic. International Journal of Training and Development, 8(2), 128139

[25] Agus, A. (2002). Production Planning Management System of production. Yogyakarta, BPFE.

[26] Nitisemito, A. S. (2001). Personnel management, human resources management (3rd ed.). Ghalia Indonesia, Jakarta.

[27] Parveen, S., Sohail, M. M., Naeem, F., Azhar, Z., \& Khan, S. H. (2012). Impact of office facilities and workplace milieu on employees' performance: A case study of Sargodha University. Asian Journal of Empirical Research, 2(4), 96-117.

[28] Jayaweera, T. (2015). Impact of work environmental factors on job performance, mediating role of work motivation: A study of hotel sector in England. International journal of business and management, 10(3), 271.

[29] Dewhurst, M., Guthridge, M., \& Mohr, E. (2009). Motivating people: Getting beyond money. McKinsey Quarterly, 1(4), 12-15. 
[30] Njoroge, S. W., \& Kwasira, J. (2015). Influence of compensation and reward on performance of employees at Nakuru County Government. Journal of Business and Management, 17(11), 8793.

[31] Pawirosumarto, S., Sarjana, P. K., \& Muchtar, M. (2016). Factors affecting employee performance of PT. Kiyokuni Indonesia. International Journal of Law and Management.

[32] Huang, C. M., Hsu, P. Y., \& Chiau, W. L. (2011). Perceptions of the impact of chief executive leadership style on organizational performance through successful enterprise resource planning. Social Behavior and Personality: an international journal, 39(7), 865-878.

[33] Raf, A.G., Desmiyanti. and Wiguna, M. (2014), Pengaruh gaya kepemimpinan, budaya organisasi, motivasi kerja dan LinLSungan kerja terhadap kinerja akuntan pemerintah (studi empiris pada perwakilan BPKP provinsi Riau), Jurnal Online Mahasiswa FE Universitas Riau, Vol. 1 No. 2, pp. 1-15.

[34] Vita, B., \& Suwarto, F. X. (2015). Pengaruh Gaya Kepemimpinan, Budaya Organisasi, Dan Lingkungan Kerja Terhadap Kinerja Guru dan Karyawan pada Yayasan Tri Asih Jakarta. Jurnal Ilmiah Penelitian, Fakultas Ekonomi Universitas Atma Jaya Yogyakarta, 1-12.

[35] Danzer, N. (2019). Job satisfaction and selfselection into the public or private sector: Evidence from a natural experiment. Labour Economics, 57, 46-62.

[36] Joo, M. K., Yu, G. C., \& Atwater, L. (2018). Formal leadership mentoring and motivation to lead in South Korea. Journal of Vocational Behavior, 107, 310326.

[37] Churchill, G. A., \& Iacobucci, D. (2006). Marketing research: methodological foundations. New York: Dryden Press.

[38] Kothari, C.R. (2004) Research Methodology: Methods and Techniques. 2nd Edition, New Age International Publishers, New Delhi.

[39] Creswell, J. W. (2002). Educational research: Planning, conducting, and evaluating quantitative (pp. 146-166). Upper Saddle River, NJ: Prentice Hall.

[40] Bougie, U. S. (2016). Research methods for business: A skill-building approach. Chichester, West Sussex, United Kingdom: John Wiley \& Sons.

[41] W.Morgan, R. V. (1970). Determining Sample Size For Research Activities. Educational And Psychological Measurement, 30(1), 607-610.

[42] Cronbach, L. J. (1951). Coefficient alpha and the internal structure of test.

[43] Birhane, G. (2016). Determinant Factors Affecting Employees' job performance in Wegagen Bank SC (Doctoral dissertation, Addis Ababa University).
[44] Nanzushi, C. Y. N. T. H. I. A. (2015). The effect of workplace environment on employee performance in the mobile telecommunication firms in Nairobi city county. A Res. Proj. Submitt. Partial, 20115.

[45] Fine, B. J., \& Kobrick, J. L. (1978). Effects of altitude and heat on complex cognitive tasks. Human Factors, 20(1), 115-122.

[46] Mohapatra, B. K., \& Srivastava, A. K. (2003). A study of the relationship of perceived work environment with job attitude, performance and health. Unpublished PhD. Dissertation, Department of Psychology, Banaras Hindu University.

[47] Naharuddin, N., \& Sadegi, M. (2013). Factors of workplace environment that affect employees performance: A case study of Miyazu Malaysia. International journal of independent research and studies, 2(2), 66-78.

[48] Njanja, L. W., Maina, R. N., Kibet, L. K., \& Njagi, K. (2013). Effect of reward on employee performance: A case of Kenya Power and Lighting Company Ltd., Nakuru, Kenya.

[49] Razak, Abdul \& Sarpan, Sarpan \& Ramlan, Ramlan. (2018). Influence of Promotion and Job Satisfaction on Employee Performance. Journal of Accounting, Business and Finance Research. 3. 18-27. 10.20448/2002.31.18.27.

[50] Banks, G. C., McCauley, K. D., Gardner, W. L., \& Guler, C. E. (2016). A metaanalytic review of authentic and transformational leadership: A test for redundancy. The leadership quarterly, 27(4), 634-652.

[51] Chandra, T. (2016). The Influence of Leadership Styles, Work Environment and Job Satisfaction of Employee Performance--Studies in the School of SMPN 10 Surabaya. International Education Studies, 9(1), 131-140.

Psychometrika, 16(1), 22-297.

[52] Harwiki, W. (2016). The impact of servant leadership on organization culture, organizational commitment, organizational citizenship behaviour (OCB) and employee performance in women cooperatives. Procedia-Social and Behavioral Sciences, 219(1), 283-290.

[53] Iqbal, N., Anwar, S., \& Haider, N. (2015). Effect of leadership style on employee performance. Arabian Journal of Business and Management Review, 5(5), 1-6.

[54] Schilke, O., Reimann, M., \& Thomas, J. S. (2009). When does international marketing standardization matter to firm performance?. Journal of International Marketing, 17(4), 24-46.

[55] Krejcie, R. V., Morgan, D. W., (1970). Determining sample size for research activities. Educational and Psychological Measurement 1970, 30, 607-610 